\title{
Gendered struggles over land: shifting inheritance practices among the Serer in rural Senegal
}

Article

Accepted Version

Evans, R. (2016) Gendered struggles over land: shifting inheritance practices among the Serer in rural Senegal.

Gender, Place and Culture, 23 (9). pp. 1360-1375. ISSN 13600524 doi: https://doi.org/10.1080/0966369X.2016.1160872 Available at https://centaur.reading.ac.uk/49149/

It is advisable to refer to the publisher's version if you intend to cite from the work. See Guidance on citing.

To link to this article DOI: http://dx.doi.org/10.1080/0966369X.2016.1160872

Publisher: Taylor \& Francis

All outputs in CentAUR are protected by Intellectual Property Rights law, including copyright law. Copyright and IPR is retained by the creators or other copyright holders. Terms and conditions for use of this material are defined in the End User Agreement.

$\underline{\text { www.reading.ac.uk/centaur }}$ 
Central Archive at the University of Reading

Reading's research outputs online 


\title{
Revised paper submitted to Gender, Place and Culture
}

Title: Gendered Struggles over Land: Shifting Inheritance Practices among the Serer in rural Senegal

\author{
Author: Ruth Evans, Department of Geography \& Environmental Science, University \\ of Reading, Reading, UK
}

\section{Author biography}

Ruth Evans is an Associate Professor in Human Geography at the University of Reading, UK. Her research focuses on gendered and generational inequalities in access to resources, responses to death and inheritance in East and West Africa. She is currently leading a research project funded by the Leverhulme Trust on 'Death in the family in urban Senegal: bereavement, care and family relations' and has recently investigated gendered and generational struggles over land in Senegal, Ghana and Liberia.

This work was supported by the University of Reading and Walker Institute for Climate System Research

\section{Acknowledgements}

I am grateful to all the family members, religious and community leaders and professionals who participated so willingly in the research. I thank Baba Sarr, Prosper Diene Faye, Soguy Ndiaye, Oumou Sougou and Laurence Marie for their research and translation assistance. I also wish to thank Prof. Abdou Salam Fall and Dr. Rokhaya Cissé, LARTES-IFAN, Université Cheikh Anta Diop de Dakar and Ian Hopwood and colleagues at the University of Reading for their support. I thank Sophie Bowlby and the anonymous reviewers for their comments which have helped to improve this paper. I am also grateful for funding from the University of Reading and the Walker Institute for Climate System Research.

\section{Contact details:}

Dr. Ruth Evans

Department of Geography \& Environmental Science

University of Reading

Whiteknights PO Box 227

Reading RG6 6AB

UK

Email: $\underline{\text { r.evans@ @reading.ac.uk }}$ 


\section{Gendered Struggles over Land: Shifting Inheritance Practices among the Serer in rural Senegal}

\section{Abstract (250 words)}

Although women's land rights are often affirmed unequivocally in constitutions and international human rights conventions in many African countries, customary practices usually prevail on the ground and often deny women's land inheritance. Yet land inheritance often goes unnoticed in wider policy and development initiatives to promote women's equal access to land. This paper draws on feminist ethnographic research among the Serer ethnic group in two contrasting rural communities in Senegal. Through analysis of land governance, power relations and 'technologies of the self', this article shows how land inheritance rights are contingent on the specific effects of intersectionality in particular places. The contradictions of legal pluralism, greater adherence to Islam and decentralisation led to greater application of patrilineal inheritance practices. Gender, religion and ethnicity intersected with individuals' marital position, status, generation and socio-ecological change to constrain land inheritance rights for women, particularly daughters, and widows who had been in polygamous unions and who remarried. Although some women were aware that they were legally entitled to inherit a share of the land, they tended not to 'demand their rights'. In participatory workshops, micro-scale shifts in women's and men's positionings reveal a recognition of the gender discriminatory nature of customary and Islamic law and a desire to 'change with the times'. While the effects of 'reverse' discourses are ambiguous and potentially reinforce prevailing patriarchal power regimes, 'counter' discourses, which emerged in participatory spaces, may challenge customary practices and move closer to a rights-based approach to gender equality and women's land inheritance. 


\section{Keywords (6)}

Inheritance

Land governance

Gender equality

Legal pluralism

Feminist ethnographic research

West Africa 


\section{Introduction}

This article shows how land inheritance rights are contingent on the specific effects of intersectionality in different socio-ecological contexts and reveals how 'reverse' and 'counter' discourses may emerge through micro-scale shifts in women's and men's positionings. The findings provide important insights into how gender discriminatory inheritance practices may be challenged and how a rights-based approach to women's land access can be achieved.

Land is central to intergenerational wealth transfers and belonging in rural spaces in SubSaharan Africa. Promoting women's equal access to land as a means of alleviating poverty has become an important priority for development policy in recent years. A recent UN (2013) report calls for a human rights-based approach to women's rights to land and other productive resources. Increased control of land and other assets by women and other marginalised groups is thought to break poverty cycles, since this often results in increased investments in the next generation's health, nutrition and schooling (ibid; Cooper and Bird 2012). Although women's land rights are often affirmed unequivocally in constitutions in many African countries, customary law regarding land inheritance usually prevails on the ground (Toulmin 2008) and may perpetuate inequalities of gender, age, class and ethnicity. Constitutional and national statutory laws (often based on the civil law of former colonial powers) may co-exist alongside Islamic law and customary law. These plural legal frameworks are open to multiple interpretations and claims (Lentz 2007) and may create confusion and barriers to gender equality and women's and girls' land rights. While there has been considerable interest in the impacts of commercialisation and recent large-scale land acquisitions (Li 2014), few studies to date have analysed everyday gendered struggles over land in rural spaces. 
This article adopts a feminist rights-based approach to land access and inheritance (UN,2013) that takes account of the plural, often competing jurisdictions which govern land access in many African contexts (Evers et al,2005). Women's claims to land are often stronger and more diverse than usually represented (Ossmone, 2014). Survey data from 15 Sub-Saharan African countries shows that older, better-educated and wealthier women are better situated to negotiate favourable inheritance (Peterman 2012). This highlights the need for feminist analyses of intersectionality and women's social embeddedness in negotiating land rights in specific socio-ecological contexts.

Senegal has experienced considerable environmental, economic and social changes in recent years, including population growth, rural exodus, land degradation and environmental pressures (Hesseling 2009). This research focuses on the Serer ethnic group ${ }^{1}$, who represent 15 per cent of the Senegalese population and live predominantly in the south-central and south-eastern parts of the groundnut (peanut) basin, long considered the 'home of some of the most "traditional peasants" in the old French African Empire' (Galvan 2004,33). The Serer also live in Dakar and other urban areas. The Serer adopted Islam and Catholicism during the 20th century, later than most other ethnic groups in Senegal (ibid). Traditionally, the Serer observe bilineal inheritance, that is, varying aspects of both patrilineal and matrilineal inheritance systems, for the transfer of wealth, values and knowledge between generations. Galvan (ibid,116) argues that the colonial process of codification of customary law discouraged matrilineal inheritance and steered the Serer towards patrilineal forms of inheritance and property holding 'thought to constitute a better foundation for industriousness and commerce'. Polygamy is slightly less common among the Serer than other ethnic groups (38\% of marriages are polygamous compared to $44-50 \%$ among other ethnicities)(Bass and 
Sow,2006). Levirate marriage, whereby a younger brother or other male relative of a deceased husband may remarry a widow, is commonly practised (ibid).

\section{Women's land rights, customary law and inheritance in Sub-Saharan Africa}

Since Agarwal's (1994) influential work on the material realities of women's relationship to the environment, a growing literature has revealed that gendered analyses of women's land rights are crucial to understanding gender relations, divisions of labour and intra-household resource use in rural spaces (Joireman, 2008). Assets such as land, financial capital and property are associated with higher status and increased bargaining capacity in intrahousehold resource negotiations (Cooper and Bird 2012). Although women are responsible for household food production in many rural communities across Sub-Saharan Africa, they usually have secondary usufruct access rights to land gained through their husband or male relatives (Toulmin 2008).

Many of the central tenets of African land tenure (such as the idea of communal tenure, a hierarchy of recognised interests in land and the position of chiefs and elders) were largely created and sustained by colonial policy and passed on to post-colonial states (Whitehead and Tsikata,2003; Evers et al, 2005). Under colonial rule, multiple types of authority and sets of claims over land were glossed as communal tenure and became incorporated into customary law. This process often served state, private European and elite African interests (Peters, 2009).

Contemporary land tenure systems and customary inheritance practices vary according to complex socio-cultural norms among different ethnic groups, colonial legacies of land settlement and allocation processes and the wider legal, religious, and political context in 
different African countries (Joireman 2008). Customary law, defined as, 'a body of rules governing personal status, communal resources and local organisation' (ibid), affects individuals as members of kinship groups and lineages, in contrast to the individual nature of statutory law.

Research and policy has only recently started to pay more attention to the role of inheritance as a key means of transferring wealth between generations in rural communities (Cooper and Bird 2012). People's social location and the support they are able to draw on within an ethnic group, family/clan, marriage, friendship, patron-client relations, and relations with authorities at various levels of society, mediate land access and inheritance (Whitehead and Tsikata,2003). Separated or divorced women often have few rights to the family home, land or jointly acquired assets, and widows may lose assets, which are traditionally held in trust for their children, to their husband's relatives after his death (Cooper and Bird,2012).

\section{Land rights and legal pluralism in Senegal}

The 'triple heritage' of African, Islamic and colonial influences is particularly pertinent to land inheritance practices in Senegal and other West African countries (Bass and Sow 2006). In Senegal, Mali and Burkina Faso, ownership of most land is claimed by the government as 'state domain' and customary occupants have use rights, as long as the land is not needed for another purpose as defined by the state (Toulmin 2008; Hesseling 2009). The French colonial powers introduced individual land ownership rights and codified customary land rights (Seck et al. 2010; Galvan, 2004). Senegal was the first former French colony to reform the colonial land legislation and the National Domain Law (1964) was considered innovative in seeking to harmonise statutory law and customary land rights (Hesseling 2009). Under this law, the vast majority (95\%) of national territory (all non-registered lands) was claimed by the state as 
the 'zones de terroir' of the 'national domain'. Farmers have free access to the land, but have no private ownership, only non-transferable use rights (ibid,249). Rural councils were established to operationalise the local administration of land governance following the adoption of the Rural Communities Law (1972) and together these laws form 'the twin pillars of national land law in Senegal' (Hesseling 2009,244).

Although the vast majority of the population is Muslim, Senegal is a secular state and the Constitution, reformed in 2001, is based on equality of women and men before the law and provides many formal rights for women, including rights to land access and to control their own property (Scales-Trent 2010). Senegal is also a signatory to the UN Convention on the Elimination of all Forms of Discrimination against Women (CEDAW), but has often failed to harmonise its national laws with the provisions mandated in international conventions (ibid).

The provisions related to succession in the statutory Family Code, originally passed in 1973, reveal some of the contradictions of legal pluralism (Camara2007). The Family Code provides for Muslims to follow Islamic law regarding the division of inherited assets, while common law provides for the spouse and his/her male and female children to inherit equal shares. In the case of a death of a male household head, Muslim daughters are entitled to only half of the estate that their brothers receive, widows are entitled to one-eighth of their husband's estate and other relatives also receive shares (Bass and Sow 2006). Widows in polygamous unions usually inherit less than those in monogamous marriages, since the widow's eighth share is divided between co-wives (Evans, 2015).

In practice, asset inheritance is usually determined within families in accordance with a mixture of Islamic law (among Muslims) and customary practices, which vary by ethnicity 
and place, and often grant women little entitlement to land inheritance. The major ethnic groups (Wolof, Hal Pulaaren, Serer, Diola) remain culturally distinctive, speaking different languages and adhering to different customary practices regulating lineage, kinship and inheritance (Bass and Sow, 2006). Inheritance practices may be more favourable for women and their children in Senegal, however, than elsewhere in Africa; 57\% of widows in Senegal reported inheriting assets compared to an average of $47 \%$ across 15 Sub-Saharan African countries (Peterman,2012).

\section{Theoretical framing}

This research aimed to examine the influence of gender, generation, religion and socioecological differences on inheritance practices and inter-vivos resource transfers among the Serer ethnic group in two contrasting rural communities in Senegal (Evans, 2012). It sought to explore whether, and how, land inheritance practices may be changing, within the context of policy discourses of women's land rights and gender equality.

Foucault's notion that power is constituted in and through discourses (which are historically variable) and creates knowledge, while knowledge itself produces the effects of power, is useful in interpreting changing land governance and inheritance practices in this article. Foucault (1978) regards disciplinary power as operating 'from below' through networks at all levels of society, subjecting individual bodies, as well as society, through self-surveillance (Foucault, 1977). This perspective is helpful in understanding how dominant power regimes shape the subjectivities of individuals and produce gendered bodies and gender relations.

Feminist poststructuralists have emphasised the multiple intersecting forms of social difference that structure women's and men's lives, including race, ethnicity/ caste, religion, 
class, disability, sexuality, as well as gender (Crenshaw, 1991). Rather than being concerned with how different systems of oppression 'add up', the notion of intersectionality seeks to analyse how race, gender, class and so on are interwoven and produce specific effects in particular places (Valentine, 2007). Nightingale's (2006;2011) work on the role of material processes and the relational emergence of nature-society builds on this understanding of intersectionality. Nightingale $(2006,180)$ calls for greater attention to be paid to how 'ecological conditions in part produce the material and symbolic work practices that constitute gender and other subjectivities, at the same time that the contestation and performance of subjectivities shape ecological change'.

Feminists have critiqued Foucault's work for paying inadequate attention to gender and how an individual may resist the disciplinary effects of power (Ramazanoğlu, 1993). Foucault's later work provides an analysis of 'technologies of the self' that McNay (1992) regards as addressing these critiques. Foucault $(1986 ; 1988)$ suggests that an individual is capable of resisting power through the very techniques through which he/she is governed. Resistance to power thus emerges through the gaps and contradictions of dominant discourses and practices, which 'provide grist for critical insights' (Li, 2007) and may lead to 'counter' discourses which oppose dominant truths (Ramazanoğlu, 1993). The operation of power may also result in 'reverse' discourses, however, which appear as 'natural' and reinforce, rather than counter, hegemonic norms (Ramazanoğlu, 1993). This paper draws on this understanding of 'technologies of the self' to explore how resistance emerges through microscale shifts in individuals' positionings, thereby producing subjectivities and possibilities for change. In this research, techniques of governance (the'technologies') include customary and religious land inheritance rules and hegemonic gender and generational norms that structure the division of labour, access to assets and participation in society. Inheritance Practices among the Serer in rural Senegal, Gender, Place and Culture. 


\section{Research methods}

A feminist ethnographic methodology was adopted to investigate changing inheritance practices and inter-vivos resource transfers among Serer families in rural Senegal. Ethnography aims to provide 'a view from below'(bell hooks, 1984) and provides 'interpretation and explanation by strategies of contextualisation'(Skeggs,1994,76). Feminist ethnography seeks to analyse the specificity of gender relations and practices in different socio-spatial and temporal contexts (ibid). Feminist ethnography and participatory approaches may potentially lead to action that challenges inequalities and power imbalances, although I acknowledge the limits and complexities of achieving this (Kesby et al, 2007).

The importance of acknowledging power relations and the selves that we 'bring' to the field as well as the self 'created' in the field have long been recognised in ethnographic and feminist research (Reinharz,1997; Skeggs, 1994). My 'brought' selves included previous research on asset inheritance and HIV in East Africa, my prior French studies background and a desire to better represent a diversity of research settings in Sub-Saharan Africa when teaching undergraduate students. My 'created' self was interested in understanding more about inheritance in a francophone post-colonial African setting characterised by legal pluralism. Following an initial scoping visit to Senegal, I undertook this independent research during three months' study leave ${ }^{2}$.

Two rural locations traditionally inhabited by the Serer were selected to provide a contrast of rural livelihood opportunities and access to natural resources and differing religious affiliations. These were 1) small villages inhabited by Muslims in the rural community of Tocky Gare, in land-locked Diourbel region, where livelihoods were predominantly focused 
on groundnut, millet, sorghum and bean cultivation and livestock rearing; 2) villages and islands inhabited by Muslims and Roman Catholics in Fimela rural community, in the coastal region of Fatick, where livelihood opportunities exist in artisanal fishing and tourism, in addition to groundnut, millet and rice cultivation and livestock rearing.

Using key gatekeepers and snowballing techniques, a purposive sample of 37 participants was identified. Semi-structured interviews were conducted with 20 participants (11 male, 9 female, aged 15-68) from 12 families who had experienced an adult relative's death in recent years (including 6 widows and 4 widowers) and with 6 male elders and religious leaders. Ten of the 12 families were Muslim and two were Roman Catholic. Where possible, two members of different generations in each family were interviewed to explore intra-household asset inheritance and inter-vivos transfers. A focus group was conducted with 4 members of a women's group in Tocky Gare and informal observations of family and community life were made in both communities. Semi-structured interviews were conducted with 11 professionals representing local and national government and NGOs working regionally or nationally.

Interpreters often play a crucial gatekeeping role in facilitating researchers' access to particular groups. I employed a Serer Muslim middle-aged man living in Dakar with a good level of education to provide French-Serer and -Wolof interpretation. The interpreter's family came from a village in Fimela rural community and due to his role as a familiar, trusted relative, I was able to undertake more extensive work in this location than in Tocky Gare, to which I gained access through a resident working for a women's organisation. I conducted some interviews with young people and adult relatives and all those with professionals in French without an interpreter. 
All audio-recordings were translated and transcribed into French with research assistance. An analytic summary of each transcript was written to assist in conducting thematic analysis and reading across the data. Following preliminary analysis, participatory feedback workshops were conducted six months after data collection in each research location with family interviewees to discuss the findings and identify key messages for policymakers and practitioners in a short video. A video-screening 'member checking ' (Harper and Cole,2012) workshop in each location ensured that participants were satisfied with the editing and their overall messages. The findings and video were discussed further in two participatory workshops with 20 participants in Fimela rural community, including rural councillors, village elders, community members and interviewees, and with 24 practitioners and researchers in Dakar.

Feminist ethnographic analysis involves prioritising some theories due to the resonance between their fundamental structures and explanation of the ethnographic material (Skeggs,1994). The interpretation of the data is informed by a rights-based approach to women's land inheritance and the theoretical framing discussed earlier. I translated quotations used in this article into English and pseudonyms have been used to protect participants' anonymity. This exploratory study does not aim to be representative of widows' and widowers' experiences in Senegal, but rather provides ethnographic insights into gendered inheritance practices in two contrasting Serer rural communities.

\section{Findings}

\section{Land governance in Serer rural communities}

As noted earlier, the National Domain law, adopted in 1964, meant that most land in rural communities belonged to the state, but farmers have free use rights to cultivate their plots 
(Hesseling 2009). Village chiefs, 'notables' (nobles) and imams descended from land-owning maternal lineages in both rural locations explained how their ancestors had founded the village, clearing the bush for agriculture by fire or axe and settling there (Galvan 2004). Such rights to rural land are often termed 'first settlement' rights (Toulmin 2008) and are the most widespread strategy used to legitimate allodial property rights in Africa, but are often based on multiple, overlapping claims (Lentz 2007). Male elders reported that later arrivals requested land from the village chief, who allocated fields that they could cultivate, on the understanding that his children would be able to reclaim the land when they needed it. Land was loaned free of charge for several years or sometimes was rented out for shorter periods for an agreed sum of money and the land returned after the harvest.

Despite the National Domain Law and the significant policy change of the decentralisation of local government in 1996 (see Ribot,2000), the 'laman' (Serer term for village land-owners) ${ }^{3}$ continued to play an important role in the allocation of land to those who requested plots in the village. The village chief and rural council were responsible for the regulation of land use rights, parcelling the land out, applying fines or compelling someone to pay for the use of land. Since decentralisation, the rural council had the right to confiscate any land that was the subject of a dispute or to reallocate under-used land, in accordance with the National Domain Law principle of productive use (mise en valeur) which assures users of the land of a certain stability (Hesseling 2009). A rural councillor confirmed, however, that the rural council was not usually involved in land inheritance, which was settled within families and communities according to customary practices.

\section{Socio-ecological change and decentralisation}


Both Fatick and Diourbel were predominantly agricultural regions focused on groundnut production. According to a Ministry of Economy and Finance representative, yields in the groundnut basin had declined over recent years due to soils being 'worn out', pushing many families into poverty. Government representatives considered that the level of land transactions in Fatick and Diourbel regions was less than elsewhere in the country. Nevertheless, population growth, land degradation and climate-related shocks resulted in increasing pressure and competition for land in both research locations. Land pressure differed between the two regions based on the specific geographies, economies and agrarian traditions (noted earlier), as well as on different manifestations of climate-related shocks; land locked Diourbel region was dependent on groundnut production as the main source of income and was exposed to land degradation, locusts and other pests, and drought, while Fatick region provided a more diverse range of livelihood opportunities (farming, artisanal fishing, tourism), but was exposed to soil salinization, destruction of mangrove ecosystems and coastal flooding.

In Fimela rural community, religious leaders and a rural council representative perceived a trend of growing land scarcity and speculation, with plots increasingly being exchanged for significant sums of money following requests to the 'laman' and the rural council. The relative stability in use rights farmers enjoyed reinforced their sense of land ownership and resulted in land transactions, prohibited under the National Domain Law, but conducted sometimes with the complicity of locally elected officials (Seck et al 2010). Tensions were apparent between rural communities and local authorities regarding villagers' rights to use and sell the land. A representative of the rural council was concerned that family members were selling portions of their land to Dakar residents or 'foreigners' without considering the longer term consequences of the loss of land for future generations. To address these Inheritance Practices among the Serer in rural Senegal, Gender, Place and Culture. 
problems, local authorities were attempting to formalise customary use rights through offering villages free registration/titling of the land they used and reallocating under-used land, but this was met with resistance from farmers. Rural councillors felt that more power needed to be devolved to enable the rural council to halt the sale and speculation of land.

Such tensions between local authorities and rural communities over land use rights could result in inter-vivos transfers of land between generations. A village chief in Tocky Gare described how he had already divided his fields between his sons and his maternal nephews in order to 'avoid conflicts' and 'any intervention from the authorities'. The chief acknowledged that his decision was unusual and some disagreed with his approach: 'It's a personal decision and some in the village don't agree with it in principle. They wait to leave and consequently, the authorities come to share out their land'. Such practices reveal how male elders and land-owning families may resist the increased power of rural councils through decentralisation and seek to protect wealth for their descendants. While such practices reveal resistance to governmental disciplinary power and the decentralisation policy, they do not challenge dominant patrilineal land inheritance practices and gender norms operating at local level.

\section{Legal pluralism and promoting gender equality in land access}

Interviews with professionals revealed considerable challenges in implementing laws and policies to promote gender equality in access to land within the context of legal pluralism, resistance from religious leaders and limited knowledge of women's rights in rural communities. The efforts of government and non-governmental organisations in campaigning for women's rights to land had achieved some success in raising awareness among rural councillors and local and religious leaders in recent years and agricultural land was 
increasingly being allocated to groups of women to cultivate. Professionals reported, however, that the collective allocation of use rights to fields or plots for market gardening to a group of women did not necessarily work very well, as it was difficult for each woman to benefit individually from her labour investment. As a Ministry of the Family representative commented: "We see collective fields that work less and less often. Now we tend to work it out so that each member of the group has a field and that develops".

Professionals emphasised that efforts to increase women's access to land and the promotion of women's groups at village level needed to be accompanied by improved access to inputs, such as seeds, as well as developing women's organisational and leadership skills to manage their business activities and increase their political participation in local, regional and national decision-making processes. Research suggests that women's access to land and civic participation often go hand in hand (IDRC 2012).

\section{Intersections of gender, religion and socio-ecological differences in inheritance}

\section{Islam and the shift towards patrilineal inheritance practices}

According to participants' accounts, traditionally, the Serer transferred land, livestock and other assets to the next generation of male heirs through customary matrilineal inheritance practices; maternal nephews (the sons of a man's sister) would inherit their uncle's assets (usually land, livestock and the family home) and sons were not entitled to any of their father's assets. Inter-vivos transfers of cattle on the occasion of a maternal nephew's marriage or for funeral ceremonies, could also be significant. Since the 1970s, however, Serer families in the research locations had shifted predominantly to patrilineal inheritance practices.

Bilineal inheritance of land continued in some villages in Fimela rural community, however, especially in those inhabited by Roman Catholics and Muslims. In Tocky Gare, the father of 
an elder interviewed and other nobles had been instrumental in petitioning for an end to matrilineal inheritance practices in the 1970s: 'Tradition preceded Islam, but Islam rejected everything which it did not agree with. Only the principles of Islam are applied here' (village elder). Although Islamic law was not applied to land inheritance, greater adherence to Islam in this community challenged customary matrilineal practices and resulted in the stricter application of patrilineal inheritance practices.

Galvan $(2004,117)$ argues that the ambiguities of inheritance and ownership in a traditionally bilineal system offered women occasional opportunities to control land and wealth, but 'Islam served as the handmaiden of imperialism by helping to limit these types of opportunities built into heterogeneous property relations'. Thus, although land was treated differently from other heritable assets in the study locations and was not divided according to Islamic law, gradual conversion to Islam among the Serer contributed to, 'a change in consciousness that greatly facilitated the standardisation of norms of property and ownership along "normal" patrilineal lines' (ibid,118). This process appears to have strengthened patriarchal power regimes in the hitherto bilineal agrarian societies of the Serer and Wolof (Creevey,1996). The cessation of matrilineal inheritance practices in the study locations was widely welcomed by male elders, imams and women, since these former practices were viewed as detrimental to widows and their children, who would have to return to their maternal relatives. As one male elder explained: "[Traditionally, when the father died....] the mother would return to her mother's hut and the maternal lineage would be responsible for them. The nephews used take the assets and come and install themselves in their maternal uncle's house". Some male elders regarded this cessation as the end of inheritance itself: 'Inheritance no longer exists'. Since this shift, land was usually passed down from fathers to sons. A similar shift from matrilineal 
to patrilineal inheritance has been witnessed in recent decades in Ghana, albeit within a different socio-ecological and religious context (author's).

\section{Gendered and generational power dynamics of land inheritance}

Whether bilineal or patrilineal systems were followed, customary inheritance practices in both rural communities demonstrate how gender and generational relations and cultural identity are intimately bound up with and expressed through the materiality of land (Li 2014). Entitlements to land were based on strict hierarchies of gender, marital position of a wife/mother, sibling birth order and generational relations. The father or eldest brother in the household was regarded as the kilifa (patriarch, head of the household and moral authority [Gning 2013]), who may or may not be the main breadwinner, but was responsible for decision-making about assets and inter-vivos resource transfers. When a married woman died, she usually had few, if any, assets to leave to her husband, children or other relatives.

Women usually accessed land through their husband's family. Wives and co-wives were often allocated smaller, marginal plots of land to cultivate, although they also worked on their husband's large cash crop fields. As women in Tocky Gare commented:

'At home, there is the head of the family, you know how things work, he is the one who is in charge. He attributes a field to each person. The large field is reserved for him and the wives content themselves with the fields that are given to them, however small they are'.

In some instances, married women continued to cultivate fields belonging to their natal families (usually their fathers or brothers). This appears to differ from the situation of women 
in other rural communities in Senegal, where they lose this right on marriage (Seck et al 2010). Aminata (Muslim) returned to her natal home for a long period when she and her husband experienced marital and financial problems and worked on her father's land. Following widowhood and levirate remarriage (to the younger brother of her deceased husband), Aminata continued to work on her father's groundnut fields during the main cultivation season in exchange for an in-kind payment: 'The fields aren't mine, they are my father's and when he sells the harvest, he buys me two or three sacks of rice because I cultivated the fields'. Although her second husband regularly stayed with her, Aminata was anxious about how she would support her five children, since her domestic work at a tourist lodge was low paid and insecure. This reveals the potential vulnerability of widows who remarry into polygamous unions and the crucial importance of women's 'sweat labour' and social relations in negotiating land use rights (Whitehead and Tsikata,2003).

Participants explained that, according to customary practices, women did not generally inherit land in Serer rural communities: 'The fields [that I cultivate] belong to my brother, but we [women] don't have fields. Here, only men have the right to own fields, not women'. This supports the findings of research from many African countries where women are not regarded as 'responsible' for land in the same way as men (Joireman 2008; Toulmin 2008). None of the women interviewed had inherited agricultural land from their husband, father or other relatives. Such gendered customary practices were justified by the fact that daughters would leave the natal household when they married, in accordance with patrilocal marriage practices, and would be allocated secondary use rights to their husband's land, as is common in many contexts (UN 2013). Three widows interviewed (one Muslim and two Catholic widows) and their children continued to have secondary use rights to their deceased husband's land and to live with his relatives after his death. This contrasts with findings from 
East Africa where widows had little access to such land and were sometimes subject to property grabbing by relatives in the context of the HIV epidemic (Evans, 2015).

Several young men interviewed whose father had died (3/4) had inherited land and other assets from their father or expected to inherit these in future. Paternal uncles would usually be entrusted with boys' inherited land and other assets until they came of age and had the means to establish their own families. This could result in delays of several years after the father's death until young men gained access to inherited assets. The eldest brother or son who was the kilifa of the family collective had considerable power to decide whether or not and when to divide inherited assets among male heirs. Younger sons and daughters, especially if their mother was a co-wife of lower social status in polygamous unions, occupied a weaker position in safeguarding their inheritance. A male elder recognised the potential injustice caused by eldest sons misusing their privileged position and misappropriating their father's assets: ' The assets that your father left, if you alone sell them, use them, whether they are horses or anything else, that's not fair and that is detrimental to his sisters, his younger brothers'. This shows how the cultural work $(\mathrm{Li}, 2014)$ involved in inheritance can be exploited by elder sons/brothers or other male heirs. It also points to the unstable and ambiguous nature of the exercise of power; the flexible application of customary law would allow for a more gender equitable reallocation of inherited assets to daughters/sisters if sons/brothers were willing to concede their position of privilege, as participants highlighted in the workshops.

Some land belonging to the maternal lineage continued to be transferred from maternal uncles to nephews in Fimela rural community. Such maternal lineage land was usually cultivated by a male elder and his maternal nephew would take over the cultivation after his Inheritance Practices among the Serer in rural Senegal, Gender, Place and Culture. 
death. From an early age fathers instil in their sons knowledge about which of the fields they cultivate belong to the paternal and maternal lineages and which they will inherit. Land belonging to Serer maternal lineages was regarded as a communal asset managed by 'a sort of co-operative', as one male elder explained, rather than being inherited and owned in the same way as patrilineal land. Frustration was expressed by some men about the way that some male elders monopolised maternal lineage fields and passed them on to their sons, often through planting mango trees and converting the field to an orchard, thereby flouting communal regulations about the use of maternal lineage land. As has been observed in other West African contexts, under customary land tenure, relatively strong individual ownership rights are granted to those who plant trees, which may lead to a shift from communal to individual inheritance rights (Rocheleau and Edmunds, 1997; Evans et al 2015).

The only land which women were reported to 'inherit' in the research locations were small rice paddy fields belonging to maternal lineages in Fimela rural community, which were usually passed down from mother to daughter or from aunt to niece. A widower explained that when Serer women moved to another village to join their husband on marriage, women were attributed to a particular maternal lineage and would be allocated lineage rice paddies to cultivate. Following a mother's death, the daughters would usually take over the cultivation of her rice paddies or they could be allocated to another woman within the maternal lineage. Similar practices of transferring some mangrove rice paddies from mother to daughter have been reported among the Diola in Casamance, southern Senegal (Seck et al.2010) and in transferring swampland controlled by women rice growers in The Gambia River Basin (Schroeder, 1997). The findings and these examples suggest that gender intersects with ethnicity, age, marital status and ecological conditions to mediate land use rights in particular socio-ecological contexts. 
Mamadou, an older Muslim widower, confirmed, "All the rice paddies that you see there are maternal lineage assets. They are managed by the maternal lineages". He explained that rice paddies were not regarded as land to be inherited, since they belonged to the maternal lineage: 'Women cultivate rice paddies through the maternal lineage. When a woman dies, it returns to the maternal lineage'. Mamadou's sister was continuing to cultivate his deceased wife's paddy fields at the time of interview, since his eldest daughter worked as a domestic worker in the city, but he reported that the fields belonged to his wife's daughters. When he remarried a widow from the same maternal lineage, Mamadou and his sister allocated a paddy field to his new wife. Male relatives may have considerable influence, therefore, on the allocation of maternal lineage land and are able to re-define who is entitled to use communal resources in different contexts.

The declining productivity of rice paddies in some areas of Fimela rural community had been reversed in recent years following an NGO development project to build a dyke to combat soil salinization. Mamadou reported that previously unproductive rice paddies were producing good yields at the time of the research. In the Fimela workshop, men and women observed that following a father's death, sons were not only inheriting their fields, but also appropriating their paternal aunt's (their father's sister's) rice paddies, which they thought was unjust. Male relatives within the maternal lineage were thus exerting greater control over rice paddies, linked to their increased productivity.

These examples illustrate how land is associated with differential bundles of use rights in rural communities which vary according to gender, generation, ethnicity, place and socioecological conditions. Use rights also change over time and can be used to exclude some to Inheritance Practices among the Serer in rural Senegal, Gender, Place and Culture. 
the advantage of others (Lentz 2007; Toulmin2008). The performance of gender and other subjectivities thus intersect at the social-relations-environment nexus (Nightingale, 2011) to influence the type and quality of assets that could be inherited by differently positioned individuals. By exploiting the gaps, ambiguities and contradictions of dominant discourses of Islamic, customary and statutory rules about inheritance, male elders and heads of maternal lineages may mis-use their position of power for their own and their sons' benefit. In so doing, 'reverse' discourses emerged of men's 'natural' rights to control maternal lineage land and rice paddies, in addition to patrilineal land, and pass these on to male heirs. Such 'reverse' discourses reinforced the prevailing patriarchal power regime and provide further evidence of the broader shift towards patrilineal land inheritance witnessed in the research locations.

\section{Intersecting inequalities in inheritance}

A widow's former status as a wife (including as a co-wife in polygamous unions), her role as a mother and social relations with her in-laws' family significantly influenced her position in inheritance, as other studies have shown (Peterman 2012). Sons enhanced widows' status and were key to safeguarding widows' continued access to land, since they would eventually become the heirs to their father's land; if widows did not have children, they usually returned to their natal families or remarried. Two Muslim widows interviewed gained secondary use rights to land through their new husband's family. If children were young when their father died and moved with their mother to her new husband's family in a different locality, children's inheritance claims to their father's land and other assets could be jeopardised.

One Muslim widow, Kangou, and her children did not inherit any assets and lacked use rights to her deceased husband's family's land. As the second wife in a polygamous union, who had an impairment and had never joined the conjugal home, Kangou had not had an opportunity 
to develop supportive social ties with her husband's family that might have provided access to their fields. She continued to live in her natal home and cultivated her father's land after marriage. She depended on the income from the sale of groundnuts to support her six children, alongside her brother's income from his work as a plumber: 'As my father can no longer farm, he gave a field to each of us [her siblings] to cultivate. We live on this land under cultivation'. Kangou's perspective about her lack of access to her husband's land and inheritance was restricted at the time of the interview by the fact that she was observing widowhood-mourning rituals, as she explained: 'In Serer tradition, one doesn't talk about inheritance while one is still in widowhood'. This shows how power is exercised through disciplinary practices and self-regulation which restrict women's speech during the liminal period of widowhood (Evans, 2014).

Delays in the division of the deceased's assets could be particularly detrimental to orphaned children and widows experiencing chronic poverty. Yangoor, an older Muslim widow who lived with her granddaughter, Khady (aged 20) and five other grandchildren, was angry with the children's paternal uncle because, three years after the parents' deaths, he had still not divided the deceased's herd of cattle which the children should have inherited, under Islamic law:

'if he noticed that the family is living in poverty, he should order that the sharing of assets be done and that the children have their share and others too [...]. In this case, if they sold their share of the cattle, they would have something to live on for months and months, but he hasn't done it, he doesn't feel any pity for the children. 
Women's low levels of literacy, limited experience of negotiating administrative procedures and dominant gender norms meant that they were often reliant on their deceased husband's male relatives to access inherited financial assets. Coumba, a Catholic widow living in Fimela rural community whose husband had worked for a company in Dakar, expected to receive his pension, but was still waiting for her husband's brother to sort out the paperwork six months after her husband's death: 'The salary that he would have received, in truth, that should be returned to me, but his younger brother came and took the children's papers to sort it out, but up to now, I haven't seen anything'.

\section{Micro-scale shifts in men's and women's positionings?}

Although many women in rural Senegal, as elsewhere in the global South, are unaware of the laws which grant them rights to land (Seck et al 2010; UN2013), women in Fimela rural community reported that they were aware that they were legally entitled to inherit a share of the land. An older Muslim widow, Yangoor commented: '.... Since the texts of Islam command it, civil law commands it, no-one can oppose it, any woman who claims her share of the land will have it. You just have to demand it'. Women reported, however, that they tended not to 'demand their rights' and accepted customary practices, suggesting that statutory and Islamic law hold little sway regarding land inheritance in rural communities. Dominant gendered power regimes operate through cohesive social norms and selfsurveillance, as most women negotiate land use rights through 'sweat labour' and building supportive social relations with kin and in-laws, rather than by seeking legal redress for inheritance claims.

In Tocky Gare, land inheritance practices were not regarded as unjust, due to the significance of brother-sister obligations for support in the event of divorce or widowhood: 'When you 
return home, it's your brother who will take responsibility for you as well as your children, so he can have a larger part' (widow). Samba, a young Muslim man in Fimela, was willing to accept that sisters should receive half the share of land inheritance that their brothers received, as stipulated by Islamic law: 'I would give her[a younger sister] land. But I would take two fields and give her one field, for example'. This acceptance of Islamic rules of inheritance suggests a micro-scale shift in attitude from the usual refusal of women's land inheritance rights under customary law. This represents a 'reverse discourse', however, which is constituted in and through the dominant Islamic discourse and does not counter the prevailing patriarchal power regime. The effects of Islamizisation thus appear ambiguous; while Islam can be regarded as beginning a deterioration of women's relative position, by reinforcing patriarchal values and solidifying them in law codes regulating every aspect of life, it also 'introduced the notion of individual rights' (Creevey,1996,280). As Yangoor and Samba's comments suggest, Islamization was accompanied by acknowledgement of women's right to inherit a share of their father's land, illustrating how power can be both productive and repressive simultaneously.

Despite this recognition of women's inheritance rights, women were regarded as only having secondary use rights to land, rather than full ownership rights and control over this land in the same way as men. Thus, inherited land comes with a 'smaller bundle of rights' for women than land that is purchased (Doss et al.2012). Indeed, in a national report, women with capital or those who have a social network that permits them to buy or rent land for agricultural activities are identified as occupying the best position in accessing land in Senegal (Seck et al2010); land inheritance is not mentioned. 
Some participants expressed progressive views underpinned by principles of gender equality, revealing 'technologies of the self' at work. Although subject to gender and generational norms that make it difficult for young women to speak out in public ('techniques of governance'), Ndiémé, a young Muslim woman, was keen to express her views about customary land inheritance practices in the workshop with her peers and wanted this message to be video-recorded and shown to local leaders, community members and NGO and government stakeholders. She emphasised the need for 'help for young girls and women in relation to inheritance' and highlighted the role that men and boys could play in supporting women 'to combat this practice', alongside campaigns by women's organisations, the equality laws and creating space for dialogue: 'If the question is discussed, a solution will be found [...] If we talk here and elsewhere, if people unite for this cause, the practice can change'. Ndiémé thus drew on the 'counter' discourse of gender equality, propounded by the secular state and women's organisations, to position herself as in favour of women's inheritance rights, thereby enabling her to 'practise a critical politics' (Li, 2007).

In a heated discussion in the Fimela workshop following the video, some Muslim men recognised the gender discriminatory nature of both customary and Islamic inheritance practices: 'the fact is that women sometimes are wronged by the two laws, customary laws and religious laws'. They thought that this led to confusion about the laws and that customary practices needed to change to keep up with 'the times', the 'evolution of things' and women's legal position. Rather than causing conflict between siblings, a male elder argued that was preferable for male relatives to support their sisters and recognise women's inheritance claims as equals: 'we should support each other, perhaps one is a man, another a woman, but no one is above the other'. Some men appeared to have been mobilised through the workshop to support women's land inheritance in future: Inheritance Practices among the Serer in rural Senegal, Gender, Place and Culture. 
'When people feel sufficiently convinced by the reality of things, they will no longer refuse. [..] We should at least support these actions, and we who have participated in this workshop should inform others to spread this more widely, so that we can support each other mutually because conflict solves nothing'.

Concerns to avoid litigation and instead change customary law through consensus-building, in line with communal norms in Senegal (Camara,2007), suggest that statutory law may 'work as a "magnet" in pulling customary practice in its direction' (Cooper and Bird 2012,536). Some women and men re-positioned themselves as in support of gender equality by drawing on 'techniques of governance' (gendered norms, statutory, religious and customary rules and practices) to explore alternative perspectives and develop counter discourses. In so doing, they destabilised the apparent 'naturalness' and authenticity of gender discriminatory customary and religious inheritance practices - during the participatory space of the workshops at least.

\section{Conclusion}

This article has shown how differentially positioned men and women contest and resist, as well as simultaneously reproduce, the homogenising effects of dominant gendered power regimes in specific places. In rural Senegal, the contradictions of legal pluralism, greater adherence to Islam and decentralisation resulted in the greater application of patrilineal inheritance practices, although they played out in differential ways in varying socioecological contexts. Gender, religion and ethnicity intersected with individuals' marital position, generation, status in the community and socio-ecological change to constrain land inheritance rights for women, particularly daughters and widows who had been in 
polygamous unions and those who remarried outside their husband's family. Rice paddies in Fimela rural community appeared to be the only parcels of land inherited by women. As the commercial value of some rice paddies increased (as a result of a development intervention to tackle soil salinization), men's perceived 'natural' ownership rights to land were asserted, even though this conflicted with Serer matrilineal inheritance practices. This is unfortunately a common story in the context of commercialisation (Izumi, 1999), which development initiatives need to guard against. Men's assertions were strengthened by Islamization and the wider shift towards patrilineal land inheritance found in both rural communities, revealing how gender, religion and socio-ecological change may insect to exclude women from land inheritance.

Despite the policy rhetoric about women's land rights, little progress has been made to date in tackling gender discriminatory land inheritance practices. Some women's and male elders' desire to reconcile customary law with statutory law suggests a willingness to adapt customary inheritance practices and move closer to a rights-based approach to gender equality. These micro-scale shifts in gendered attitudes show how 'counter' discourses may start to destabilise dominant gender norms. However, the effects of 'reverse' discourses were more ambiguous; Islamic law provides for widows' and daughters' inheritance rights, but is usually based on gender discriminatory rules which further justify men's claims for patrilineal land inheritance. Efforts should focus on building consensus and support among local and religious leaders, men, women and young people on the principles of gender equality in land inheritance and on raising awareness of women's and girls' legal and human rights (UN 2013). 
Rather than 'technologies of the self' being seen only as an individual process concerned with 'refashioning identities' (McNay, 1992), this article has shown how participants may reposition themselves through a shared, collective process (Li, 2007). Such shifts in women's and men's positionings may enable them to develop critical insight into hegemonic gender norms and thereby help to unsettle truths and perceptions of men's 'natural' land inheritance rights. Men and women who expressed a progressive desire for gender equality, however, may find it difficult to perform in empowered ways once they leave participatory arenas (Kesby et al,2007). Thus, although inequalities are constantly shifting and open to reinterpretation, they are also 'surprisingly resilient to major reconfigurations' (Nightingale, $2011,161)$.

Given the socio-political power regimes governing land access and unresolved gendered struggles over land rights, notions of flexibility and negotiability in social relations and the governance of land in Africa should not be overemphasised (Peters,2009). Continual assessment is needed of the intersection of gender, generation, age, religion, ethnicity, marital position, class/affluence and other socio-ecological differences in reproducing inequalities. Such an approach can provide insight into how winners and losers in gendered struggles over land are produced in specific contexts, as rural communities are increasingly exposed to socio-ecological change and commodification.

\section{Endnotes}

1. I recognise that the ethnic category 'Serer' is an umbrella term employed since the colonial era that groups together heterogeneous populations from seven major sub-groups (Galvan, 2004). Participants identified with the term 'Serer' and did not specify a sub-grouping. 
2. This research was funded by [author's institution]2011-2012. Ethical approval for the research was granted by [author's institution] in 2011 and 2012.

3. In one of the research locations, the imam was the village 'laman', showing how class/affluence may be interwoven with religious authority and status in rural communities.

\section{References}

Agarwal, B.1994.A Field of One's Own. Gender and Land Rights in South Asia.Cambridge:Cambridge University Press.

Bass,L. and Sow,F.2006."Senegalese families: the confluence of ethnicity, history and social change".In Oheneba-Sakyi,Y. and Takyi,B.(Eds.)African Families at the Turn of the $21^{\text {st }}$ Century 83-102.Westport:Praeger Publishers.

Camara,F.K.2007."Women and the Law: A Critique of Senegalese Family Law".Social Identities 13:787.

Cooper, E. and Bird,K.2012."Inheritance: a gendered and intergenerational dimension of poverty."Development Policy Review 30(5):527-541.

Creevey, L.1996."Islam, women and the role of the state in Senegal".Journal of Religion in Africa 26(3):268-307.

Crenshaw, K.1991."Mapping the margins: intersectionality, identity politics and violence against women of color".Stanford Legal Review 43:1241-1299.

Evers, S. Spierenburg, M. and Wels,H.2005."Introduction - competing jurisdictions: settling land claims in Africa, including Madagascar".In Evers,S., Spierenburg,M, and Wels,H.(eds). Competing Jurisdictions. Settling Land Claims in Africa1-19. Leiden: Brill.

Foucault, M.1977.Discipline and Punish. New York:Vintage Books.

Foucault, M.1978.The History of Sexuality. Volume 1.London:Penguin Books. 
Foucault, M.1986.The History of Sexuality. Volume 2.The Use of

Pleasure.Harmondsworth:iking.

Foucault, M.1988.The History of Sexuality. Volume 3.The Care of the Self.London:Penguin Press.

Galvan, D.2004.The State must be our Master of Fire. How Peasants Craft Culturally Sustainable Development in Senegal. Berkeley and Los Angeles: University of California Press.

IDRC(International Development Research Centre)2012."Equality a collective effort in Senegal". Women and Land in Focus Case Study, Senegal, www.idrc.ca[accessed 26/4/12]. hooks, B.1994.Feminist Theory: From Margin to Center. South End Press, Boston. Izumi, K.1999."Liberalisation, gender and the land question in Sub-Saharan Africa", Gender and Development 7(3):9-18.

Joireman, S.2008."The mystery of capital formation in Sub-Saharan Africa: women, property rights and customary law."World Development 36(7):1233-1246.

Lentz, C.2007."Land and the politics of belonging in Africa". In P. Chabal, U. Engel and L. de Haan (Eds) African Alternatives 37-54. Leiden: Koninklijke Brill.

Li, T.M.2007.The Will to Improve. Governmentality, Development and the Practice of Politics. Durham \& London:Duke University Press.

McNay, L. 1992.Foucault and Feminism. Power, Gender and the Self.Cambridge: Polity Press.

Nightingale, A.2011."Bounding difference: Intersectionality and the material production of gender, caste, class and environment in Nepal".Geoforum 42:153-162.

Nightingale, A.2006."The nature of gender: work, gender and environment".Environment and Planning D. Society and Space 24(2):165-185. 
Peterman, A.2012."Widowhood and asset inheritance in Sub-Saharan Africa: empirical evidence from 15 countries".Development Policy Review 30(5):543-571.

Peters, P.2009."Challenges in land tenure and land reform in Africa: anthropological contributions". World Development 37(8):1317-1325.

Ramazanoğlu, C.1993."Introduction". In Ramazanoglu, C.(ed) Up Against Foucault.

Explorations of some tensions between Foucault and Feminism 1-25.London:Rouledge.

Ribot, J.2000."Decentralization, Participation and Representation: Administrative apartheid in Sahelian Forestry".In Peters,P.,(ed.) Development Encounters: Sites of Participation and Knowledge. Cambridge: Harvard University for HIID.

Rocheleau, D. and Edmunds,D.1997."Women, men and trees: gender, power and property in forest and agrarian landscapes".World Development,25(8):1351-1371.

Scales-Trent,J.2010."Women lawyers, women's rights in Senegal: the Association of Senegalese Women Lawyers."Human Rights Quarterly 32:115-143.

Seck, S, Touré O., Ba, CO, Faye, J., Diop, D. and Fall, M.2010.Revue Documentaire. Analyse des practiques foncières and des enjeux de la sécurisation foncière au Sénégal. Initiative Prospective Agricole et Rurale. Avril2010.

Skeggs,B.1994."Situating the production of feminist ethnography".In Maynard M. and Purvis J.(eds) Researching Women's Lives from a Feminist Perspective 72-92. Abingdon:Taylor and Francis.

Toulmin, C.2008."Securing land and property rights in sub-Saharan Africa: the role of local institutions."Land Use Policy 26:10-19.

UN (United Nations)2013.Realising Women's Rights to Land and Other Productive Resources. UN Office of the High Commissioner for Human Rights and UN Women, Geneva and New York. 
Whitehead, A. and Tsikata,D.2003."Policy Discourses on Women's Land Rights in SubSaharan Africa: The Implications of the Re-turn to the Customary." Journal of Agrarian Change3:67-112. 